\title{
Property Business Digital Marketing Communication Strategy During The Covid-19 Pandemic At Kartika Residence
}

\author{
Yunita $^{1 *}$, Amri Dunan ${ }^{2}$ \\ ${ }^{1}$ Departement of Marketing Communication, Gunadarma University, Depok \\ ${ }^{2}$ The Ministry of Communication \& Informatics, Jakarta \\ ${ }^{*}$ Corresponding author: \\ Email: yunitasartika6@gmail.com
}

\begin{abstract}
.
This research aims to find out the digital marketing communication strategy of the property business during the Covid-19 pandemic at Kartika Residence. The methods in this research use qualitative research using the theories Diffusion of Innovation and E-marketing. The analysis was conducted with the theory of Diffusion of Innovation and E-Marketing. The results showed that digital marketing communication in the Kartika Residence property business is a container in building branding on digital media and promoting products. E-marketing, although helpful as a sales support tool, but the sales process will be able to be done if consumers have visited the location. So that the use of digital marketing is only at the stage of branding, promotion, prospecting, and then follow up.
\end{abstract}

Keywords: Marketing Communications, Digital Marketing, Property, Covid-19

\section{INTRODUCTION}

Massive infrastructure development throughout Indonesia initiated by Joko Widodo and Jusuf Kalla (Jokowi-JK) is believed to accelerate Indonesia's economic development, including the property sector. It can attract interest from foreign investors to make investments in Indonesia if the supporting infrastructure is adequate[1]. The property industry is one of the industrial sectors that are very important for economic growth in Indonesia due to the many derivative industries in the business sector. In the 2020 financial report, the company recorded total revenue of Rp5 trillion. Property development business still contributes the highest revenue with operating income of Rp3.7 trillion or contributes 73 percent of total revenue and operating profit of Rp1.23 trillion or contributes 96 percent of the company's total operating profit Rp1.27 trillion[3]. The existence of a policy of building one million houses per year by the government for the community, which includes LowIncome Community (MBR) and non-MBR homes, has also been one of the driving factors of the property business in recent years, which increases people's purchasing power towards property[4]. With the community's housing needs that have increased, the property business becomes a business that has increased rapidly every year. The growth of a country generally starts from the property sector. The property sector is like a locomotive that attracts several other business sectors such as banking, construction, civil architects, planning and business sectors, and other property fields [5].Karawang Regency is one of the areas currently developing, both industrial sector, property, housing development. It is inseparable from the development of the Karawang region into an industrial area. That urbanization or residents who come from outside Karawang to work in the Karawang region [6]. With the economic improvement in Karawang, in the end, the need for the residential sector, malls, and shops and the need for transportation access also increased.

The emergence of market needs, wants and demands encourages producers to study, conduct market research, observe consumer behavior, analyze complaints and dissatisfaction experienced by consumers. It is essential because manufacturers can offer good goods, services, and ideas to the market to get a good response 
[7].The national economy continues to experience a resurgence amid the Covid-19 pandemic. The property sector was severely affected when the beginning of the Covid-19 pandemic entered Indonesia. Optimism about an increase in the positive direction in the property sector arises from the belief of property market participants that the Covid-19 pandemic is the right time to invest in the property world [8]. Property is still considered the prima donna of investment because it has an asset value that increases without much fluctuation and relatively low risk. The housing sector and industrial estates are the five main business sectors that recorded the highest investment realization of $\mathrm{Rp} 29.4$ trillion (3.4 percent) in 2021[9]. The need for a home is one of the basic needs for humans after food and clothing. Every individual human being will prioritize the fulfillment of basic needs rather than secondary needs. Property is vacant land or a piece of land developed, used, or provided for residence. In determining the selection of a house as a place to live, consumers look at the price factor and begin to consider several other factors such as the location, building, and comfort factors of an environment. More housing demand will become more complicated, and developers will try to improve housing quality and service, such as strategic locations, guaranteed conditions, and complete facilities [10].

Meanwhile, property competition in Karawang city is relatively high with the entry of several developers in this city. It brings a positive impetus to make innovations in selling their products continually - both from the promotional strategy provided and the service aspect from the consumer side. One of the property developers in Karawang city is Citra Swarna Group by developing the Kartika Residence Karawang residential project on an area of 140 hectares with an investment value of Rp 1.5 Trillion. Among many similar housing competitors in Karawang, but Kartika Residence still exists. It is evidenced by an increase in sales charts during the Covid-19 period from March 2020 to March 2021. Digital marketing communication strategy becomes one of the essential things to support success in the sales process.Kartika Residence has received an award from PT.Bank Tabungan Negara (Persero) Tbk is the "1st Champion of Non-Subsidized Credit Realization" in the 2017 Karawang branch. "Champion 1 Developer of The Largest Non-Subsidized Mortgage Realization" in 2018, "Achievement Award success against the target of 100 Billion" in 2018 \& 2019, "Rank II Developer Category of Realization of The Most Online Mortgage" in 2020, and in April 2021 Kartika Residence received the award "Most Favoured Middle-Class Housing Project Big Scale in Karawang" from Urban City. It makes the reason for determining the Kartika residence research object based on the sales results alone and supported by the achievement factor achieved by Kartika Residence. Based on the description above, researchers felt the need to conduct a study entitled "Digital Marketing Communication Strategies on Property Business in the Covid-19 Pandemic." (Descriptive Study at Kartika Residence).

\section{METHODS}

In this research, what will be discussed is how the digital marketing communication strategy carried out by Kartika Residence. The subject and object of research are important goals in obtaining the purpose of a study that will be proven objectively. Understanding of the subject and object of research according to Sugiyono, the subject of research is an attribute or nature or value of people, while objects or activities have certain variables that will be determined to be studied and drawn conclusions [11]. The subjects of this study were the General Manager of Marketing and the Sales Marketing Team. In contrast, the object in this study is the Marketing Department at Kartika Residence housing developed by Citra Swarna Group and PT. Artha Graha Sedayu as sub-developer. This research uses descriptive qualitative research methods. Qualitative research is widely used in research in the social field. Qualitative research uses not statistics, but data collection, analysis, and interpretation [12]. This research method prefers to use in-depth analysis techniques that examine problems in case because the active skin methodology is confident that the nature of one problem will be different from the nature of the other problem[13].Data collection techniques are part of a study due to how researchers collect the data required in their research. In this study, the authors used a planned interview. Usually, a list of questions has been prepared in advance and systematically compiled. Then by the interviewer asked the respondent by reading 
to answer. All respondents were selected and then submitted questionnaires, words, patterns, and systematics alike [15].

The study also used subjective observations from Kartika residence' official social media. Observation is the observation by a method of systematic recording of the symptoms that are being studied. Observation becomes one of the techniques of data collection if: following the purpose of research, planned and recorded systematically, and can be controlled by its circumstances (reliability) and validity (validity) [16].The instrument used in this study is to conduct interviews either in person or online. Instruments play a crucial role in determining the quality of research because the validity or validity of the data obtained will be primarily determined by the quality or validity of the instrument used and the data collection procedure taken. The instrument or research tool in qualitative research is the research itself, so the researcher must be "validated." Validation of researchers includes understanding quantitative research methods, mastery of insight into the field studied, and readiness of researchers to enter the object of research researchers both academically and logically [17].

\section{RESULT AND DISCUSSION}

The results and discussions in this study are obtained from field data obtained from descriptive qualitative research. In this study, the authors analyzed how digital marketing communication strategies in the property business in the Kartika Residence housing project at the time of the Covid-19 pandemic. The existence of the Covid-19 pandemic brought changes in the business cycle, especially businesses in this property field.

Sales Graph Analysis. The Covid-19 pandemic forced everyone to adopt, as well as the property business world. The Covid-19 virus restricts the movement of property businesses at the beginning of its emergence. Nevertheless, the sales figures on the Kartika Residence housing project when compared to 2019 are slowly increasing. Although in March 2020 there was a drastic decline, the pace of sales of housing units in the following months in Kartika Residence gave good results. According to Mr. Hengky Japri, the increase in sales before the Covid-19 pandemic and after Covid-19 was almost doubled. Here is a chart of sales for the period 2019 to March 2021 as comparison material.

Fig 1. Sales Data 2019 - March 2021

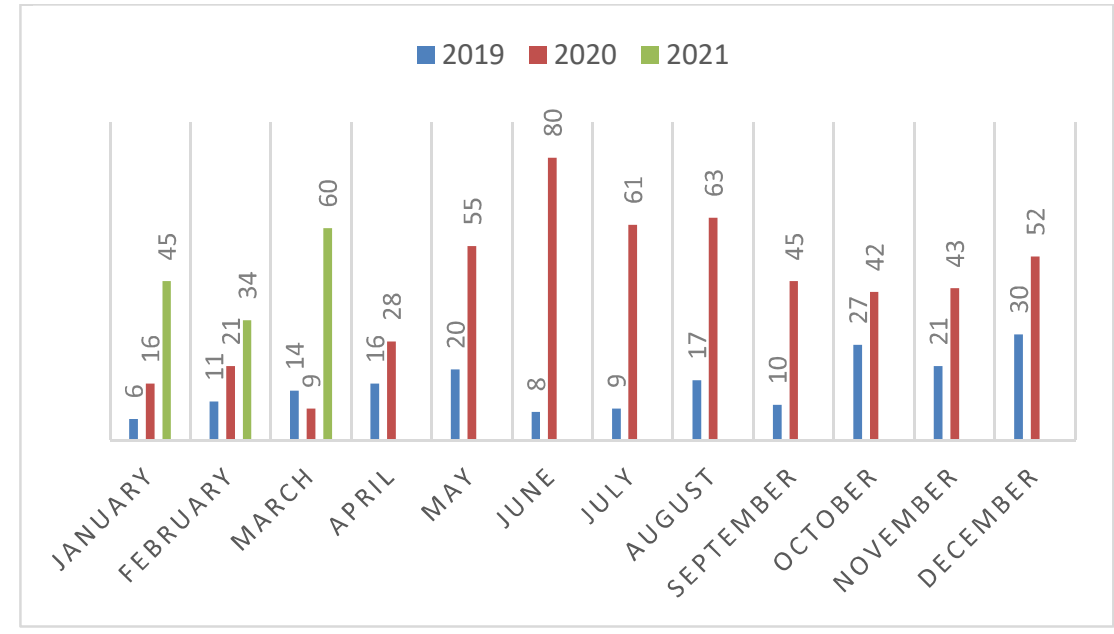

Source: Data processing results by Yunitaeserher

The main factor influencing sales for the initial stage or new management is how to build an organization in this case, the structure of team building leads to progressive. Internal factors become an evaluation of how the management of Kartika Residence can be a faster adaptation by evidenced by sales figures before the Covid-19 virus period exists. At the same time, other external factors are using as much as possible digital marketing so that the market knows a lot about products from Kartika Residence despite restrictions on promotional activities such as canvassing, exhibitions and open tables. Then during the Covid-19 pandemic hit 
the world, there was a policy from banks regarding low-interest rates and supported by policies from the government in the form of free VAT. Internal and external factors are what can improve sales figures every month.

\section{Marketing Communication Strategy Model}

Marketing communication strategy is an essential component in the company's successful sale of either goods or services. It is useful to know what the plan is thorough, integrated, and integrated between the elements of communication and marketing, which will later guide what activities will be carried out to achieve a marketing goal in the company. The following is a model of marketing communication strategy used by Kartika Residence when Covid-19 was detected in Indonesia, especially in Karawang city. Here is a chart of the marketing communication strategy model implemented by Kartika Residence.

Fig 2. Kartika Residence marketing communication strategy model

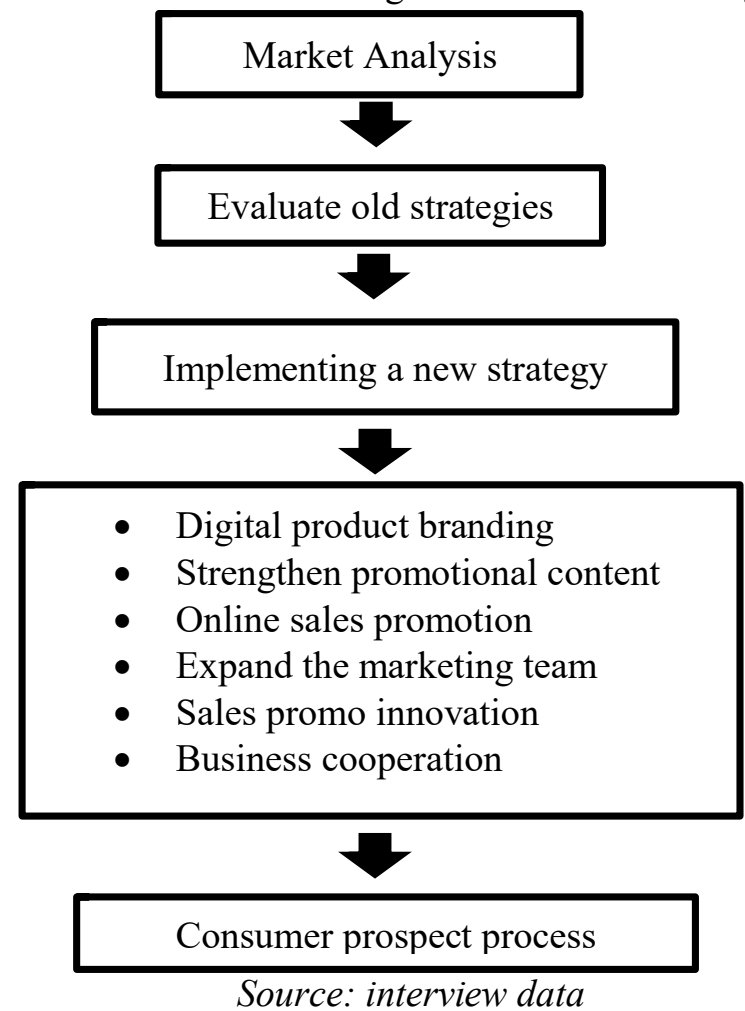

As for the strategy that has been implemented and is still effectively run by the author summarizes into six main points that must be carried out both from the management level to the level of the marketing team and the marketing support division.

\section{Digital product branding}

The transition is packaged with a particular concept from the conventional to the digital way. Branding products using digital media has been done. It is just that the previous branding concept is still not patterned, and the intensity of posts in the media has not been scheduled. Branding is more dominant in social media, Instagram and Facebook. The Markom division does this digital branding.

\section{Strengthen promotional content}

At this point, it is related to product branding because every promotional content, be it the theme about sales and branding as a whole must be interrelated and following the concepts that have been formulated.

\section{Promotion of product sales through online}

Sales promotion through paid online is a program of management. Every marketer must create ads on property buying and selling sites and social media with targets per week. 


\section{Increase the marketing team}

Multiplying and strengthening the marketing team is because more and more sources are spreading information about Kartika Residence products, the opportunity to get prospective customers will be more excellent.

\section{Innovation on sales gimmicks}

Gimmick sales here is a promo program made to attract market purchasing power. Of course, for promos run by Kartika Residence, it must be different from competitors in karawang city.

\section{Increase cooperation for B2B scale sales}

Cooperation strategy with business to business scale either with property agents or with property members that have been coordinated becomes an essential point in sales at Kartika Residence. Because in addition to consumers from marketing itself, there are references from other sources, namely property members or property agents.

\section{Theory of Diffusion of Innovation in Research Results}

The world of property is a business whose loss rate is minimal in terms of consumers who buy products. Because property is an asset with an investment value that continues to increase, especially supported by infrastructure and facilities factors either in the project or outside the project. This can increase the price of the property. But if the developer company cannot manage the project correctly, then the investment value owned by the product will be difficult to increase. Not a few also development projects both housing concepts, apartments and the like there are mangkrak. The author is conducting this study uses the theory of Diffusion of Innovation, by dividing it into four dimensions :

\section{Innovation (ideas, actions, or goods) that are considered new.}

In the dimension of innovation, the author focuses on the company's development in making new ideas to maintain sales figures. The management of Kartika Residence, making an idea by issuing sales promos such as flat mortgage interest subsidies for two or three years depending on the type of unit. The idea of this mortgage interest subsidy promo previously did not exist in Karawang City. The second innovation is DP 0\%. DP $0 \%$ is done because it makes it easier for prospective consumers who want to own a house to not be charged DP. This effectively attracts buying interest from consumers. As a result, even if the prospective consumer does not have the spare money to pay Done Payment, prospective consumers are enough with 1,000,000 dollars, - as a booking fee only.

2. Communication channels is a tool to convey messages of innovation from the source to the recipient.

In the dimensions of communication channels, the author focuses on the media often used to convey sales promo information. Channels or communication media used to spread this information are social media such as Facebook, Instagram, and Whatsapp application as the main media in communicating with prospective consumers.

\section{Time period of time required by consumers.}

From the interview results with Mr. Hengky Japri, the time needed by his team in making prospective consumers receive information and up to the average closing takes about one to two months depending on the time provided by the consumer.

4. Social systems are a collection of functionally distinct units and are bound in cooperation to solve problems to achieve common goals.

In the social system in terms of authors focused on how to manage Kartika Residence strengthens cooperation with btn bank in the mortgage application process. Cooperation, in this case, BTN becomes the only partner in Kartika Residence in the mortgage process, so that all consumers who have purchased at Kartika Residence will be in agreement with BTN bank. 


\section{E-Marketing on research results}

The second theory used by the author to dissect the digital marketing side is to use the e-marketing theory. The author focuses on how to communicate the content of the message to the audience. internet. EMarketing is an effort by a company to inform, communicate, promote, and market its products and services through the internet. E-marketing contains all of the online or electronic-based activities facilitated by the manufacturer to satisfy customers. E-Marketing by leveraging technology through networking can coordinate market share research, help develop products, develop strategies and tactics to attract customers, provide online distribution, maintain customer records, create customer satisfaction. E-marketing can advance marketing programs that support the company's goals of implementing e-commerce. The author in linking the results of the study with the theory of e-marketing using seven stages consisting of:

\section{Analysis of the situation.}

In this situation analysis, the author goes more profound using SWOT analysis. SWOT analysis aims to analyze the internal (strengths and weaknesses) and external (opportunities and threats) of the company on which this analysis is based. In the discussion of SWOT analysis, the author divides it into several points based on the results of interview data that has been conducted.

\section{A. Determining internal factors as Strengths and Weaknesses}

The relevant factors as the strength of the Kartika Residence housing project consist of housing facilities, location of housing locations, accessibility, choice of house type, and the number of units. The second internal factor is the Kartika Residence housing project's weakness: house prices, building quality, immediate access has not been built, the construction period, and the governance of facilities has not been maximized. The explanation of each of these points is:

\section{a. Power}

1. Completeness of housing facilities.

Kartika Residence has several supporting facilities to make its residents comfortable. Consists of: green open space, lake, food park, commercial area, school, worship facilities, water park, sports area, clean market, health facilities.

2. Location of residential location

The location of the location is the floor plan or position of the housing that is built. Located in East Karawang, Kartika Residence becomes a somewhat strategic housing because of the residential location close to Klari station, East Karawang toll gate and Klari Terminal.

\section{Accessibility}

Accessibility is the smooth transportation to residential locations. For access to Kartika residence housing, it takes about 5-10 minutes from the national road. But for the immediate access will be moved which is integrated directly with the East Karawang toll gate. So that in the future, the primary access does not pass through the streets of people's homes.

4. Choice of home type

The type of house is the area of the house unit building designed and built by the developer. For the choice of unit types in Kartika Residence has many unit types consisting of type 30/72, type 38/72, type 60/72, type $45 / 90$.

\section{Number of housing units}

The number of housing units is the suitability of the number of houses built by the developer in the location. Because Kartika Residence made the cluster concept, the number of housing units built is 200 for each cluster.. 


\section{b. Weakness}

1. House prices

House prices in Kartika Residence can be categorized as quite expensive for prices in East Karawang compared to similar housing. Not without reason why the price of housing in Kartika Residence is quite high, because it is a supporting facility and the development of a progressive master plan.

2. Building quality

Regarding the quality of the building, the results of direct observation to the field can be said to be an improvement in terms of building quality. Some unfinished buildings are built, not maintained because the progress of its construction is delayed.

3. Primary access that has not been built

As explained in the power factor, the direct access to be moved and closer to the East Karawang toll gate is still no progress. So that temporary access is still through the surrounding residents' housing.

4. Development period

The construction period carried out by Kartika Residence takes six to twelve months if there is no delay. Nevertheless, the findings on the ground, the authors found several cases of delayed development that resulted in the handover process of the unit keys suffered a setback.

5. Facility governance has not been maximized

Governance in facilities in housing is still not maximal, the findings on the field of the author found some areas that have not been maximized care. Recognized by the informant, that his governance of the Estate Management division is still not maximal for its development and maintenance.

\section{B. Determining external factors as Opportunities and Threats}

External factors that affect the continuity of sales from Kartika Residence consist of ten points, dividing five category points as opportunities and five points as a threat. The explanation of each of these points is:

\section{a. Opportunity}

1. Market potential

Market potential is the purchasing power of the community's need for housing. Karawang city has good market potential because the primary sector supporting its economy is the industrial sector. Employees who work in the industrial sector are not entirely Karawang people but from various cities in Indonesia.

2. Community income

Referring to the decision of the Governor of West Java No. 561 / Kep.774-Yanbangsos / 2020 on minimum wage of regencies / cities in West Java Province in 2021, umr karawang city 2021 has been set at Rp 4,798,312 per month. UMR Karawang city is the highest UMR district/city level in Indonesia. This makes the opportunity for people's purchasing power with sound financial,

3. Immigrants

Karawang city as an industrial city, as already explained in the number one previously that employees who work in other industrial sectors come from outside the city of Karawang. The potential to have a house is quite large because they do not have their own residence.

4. Concept of project development that does not yet exist in East Karawang

Kartika Residence has the concept of development as an independent city in the future. This makes a good point because in East Karawang, there are still no developers who carry the development of making it an independent city.

5. There are still many development areas open.

The land around the Kartika Residence project is still many rice fields and yards that can be used as a list for land acquisition for future development. So that if the purchasing power of the market increases and there is a change in the master plan for management expansion, there is no difficulty finding vacant land. 


\section{b. Threat}

1. Continuous-wave of Covid-19 pandemic

Until July 2021, the Covid-19 virus in Indonesia is still many cases. Every day there is an increase in the number of positive Covid-19. Thus allowing the effects of the Covid-19 pandemic on the property sector could disrupt the market's purchasing power.

2. Changes in banking interest rates

A change in banking interest rates is the interest rate on loans related to the property business. If the change in interest rates from banks is high, then the promo interest subsidy from developers also goes up so that consumer installments are not so high compared to other housing.

\section{Competitor prices}

The price of pesain is a price comparison between one developer and another developer. House prices are a significant factor when prospective consumers make their choice.

\section{Promotion from competitors}

Competitor promotion is an activity carried out by competitors. If the promotional activities of competitors are more attractive, it will affect the number of guests who visit the location.

\section{5. layoffs}

As a result of the Covid-19 pandemic, many employees are not imagined to be laid off or even laid off. If the industrial sector, especially in the surrounding city of Karawang, will experience this, the market's purchasing power will decrease.

\section{E-Marketing strategic planning}

In this analysis, the author uses the concept of market opportunity. From the analysis that has been planned and developed by the management, especially the marketing division, the e-marketing strategy plan developed into several points, namely:

a. Use digital marketing as a medium in promoting products.

Utilization of digital media as a form of adaptation during the Covid-19 pandemic. Because some activities are restricted and even prohibited such as exhibitions in malls, open tables, canvasing restrictions, and direct promotional activities. Launch of the fourth cluster with a different concept and design than the previous cluster.The fourth cluster is named Kahuripan, a breakthrough for Kartika Residence by making the concept of "liven up the environment" by increasing public space in the cluster. The launch of this new cluster wants to find out the market's appeal to new products from Kartika Residence.

\section{Purpose}

In making a marketing communication strategy plan, the main goal is to deliver product information to the target audience. From the data obtained by the author at the time of the interview, the purpose of making a marketing communication strategy is:

- Sales teams are increasingly getting guests to be used as prospects from ads in digitalized media.

- Achieving sales targets from each sale and SPV

- More and more people know Kartika residence housing information

\section{4. $\quad$ E-Marketing Strategy}

In creating an E-Marketing strategy, the author focuses on analyzing the marketing mix, which consists of:

\section{a. Product}

Kotler and Armstrong define that a product is all that can be offered to the market to attract attention, acquisition, use, or consumption that can satisfy a desire or need. Products in broad terms may include physical objects, services, ways, people, places, organizations, ideas, or the mix of these entities [18]. At the same time, the products sold by Kartika Residence consist of housing units and shophouses for commercial areas. This type 
of unit consists of type 30/72, type 38/72, type 60/72, type 45/90. As for the type of product on the shop itself only consists of one type, namely type 45/90.

b. Price

According to Firli the price of the product is basically the amount paid by the customer to enjoy it. Price is an essential component in the definition of a marketing mix. It is also a vital component of a marketing plan as it determines the profit and survival of the company [19]. Adjusting product prices has a huge impact on the overall marketing strategy and greatly affects product sales and demand. Price always helps shape the perception of the product in the eyes of consumers. For the price of products from Kartika Residence starting from Rp. 495.000.000.- up to 960,000,000,- for home products. As for shop products range 1,380,000,000,-

c. Place

Placement or distribution is a crucial part of the definition of a product mix. The company must position and distribute a product in a place that is accessible to prospective buyers. It comes with a deep understanding of the company's target market, understand them from within, and find the most efficient position and distribution channels [20]. The strategy carried out by Kartika Residence in placing or distributing information about its products is to create two offices located in different locations. The office for administrative purposes is addressed in Ruko Indah, Jalan Raya Klari No.23-24, Kondangjaya, East Karawang. As for the marketing office located within the Kartika Residence Area itself which is located at Jl. Gintung Kerta, Klari, East Karawang.

d. Promotion

Promotion is an essential marketing component because it increases brand recognition and sales. Advertising usually includes paid methods of communication such as television advertising, radio advertising, print media, and internet advertising. There seems to be a shift in offline focus to the online world in this day and age. Advertising is the most widely done form of promotion (Firli, 2020:17). The promotion method carried out by Kartika Residence as a form of communication from the company to prospective consumers is widely done with digital media such as advertising on Instagram, Facebook, WhatsApp, and property buying and selling sites. The form of conventional promotion that is still used is the installation of billboards, banners, and mouth of mouth methods or can be said to be a form of informal communication promotion involving get members, the buyer gets buyers, or other references.

\section{Implementation Plan}

The plan to implement a strategy that has been chosen requires the company to set short- and long-term goals, create a policy, motivate employees, and allocate resources so that the strategies that have been formulated can be appropriately executed. The application of strategies includes developing a supportive culture on strategy, creating effective organizational structures, and re-deployment of marketing efforts [21]. In implementing the implementation plan of the strategy that has been set, the management, in this case Mr. Hengky Japri, as General Manager, conducted a pattern of internal reshuffle first. Such as forming a core team closely related to sales, namely the Sales Division, Communication Marketing Division and mortgage division. Every strategy that will be used previously will be held meetings and maturation of ideas or concepts. Meetings can be held three times a week depending on the level of urgency.

\section{Budget}

Budget allocation for communication marketing purposes is only used for budget posts that significantly affect sales. Promotional budgets can be made based on the planning that has been made. The creation of budget allocation is based on the type of promotion that will be done and adjusts the situation and conditions of the product. The purpose of making this budget is to facilitate planning, organization, implementation and control. This promotional budget must be approved by all departments involved [22]. In the budget allocation used by Kartika Residence for promotional purposes, the Marketing Department uses a budget allocation of about 1 to 1.5 percent. The budget is from the bank's disbursement of unit purchases. 


\section{Evaluation}

The type of evaluation depends on the purpose of the plan. To determine the evaluation results, companies can use a balanced scorecard to measure the success of internet marketing programs and whether the program is following the company's objectives (Firmansyah Anang, 2019: 58). Evaluation conducted by management, especially the Marketing Department, is not only focused on using internet marketing programs only. Nevertheless, evolution here focuses on several points such as team performance, sales points, target databases, targeted prospective consumers who visit the location and evaluation of previously held events.

\section{CONCLUSION}

This research discusses communication strategies in the context of digital marketing. Referring to the observation and interviews with four informants, the use of digital marketing for the need for marketing communication in the property business, especially Kartika Residence during the Covid-19 pandemic, has a positive effect that facilitates the process of advertising and branding. One of the innovations used using sales promos that previously did not exist in Kartika Residence. It is a unique attraction because the promo is not all developers use, especially in Karawang. Suppose this research is associated with e-marketing by examining how the marketing process utilizes the internet's development. From this analysis, there is a management of digital marketing media as a container in branding and conducting product promotion.Nevertheless, in the e-marketing property business, although it helps as a sales support tool, the closing process will be able to be done if consumers have visited either the office or the example home at least once. So that the use of digital marketing is only at the stage of branding, promotion, prospecting, and then follow up only. The rest of the consumers will still visit the unit to check directly how the housing condition is from the area or the example house.

\section{REFERENCES}

[1] Hariyani Iswi, dkk. 2021. Property Top Secret : Buku Pintar Bisnis \& Invetasi Properti di Era Revolusi Industri 4.0. Yogyakarta : Penerbit Andi.

[2] Irdy Eka M.M, dkk.2020. Strategi Pengembangan Bisnis PT. Adhi Persada Properti.Jurnal Aplikasi Manajemen dan Bisnis, Vol. 6 No.2 Mei 202 https://jurnal.ipb.ac.id/index.php/jabm/article/view/27342

[3] https://www.minews.id/news/industri-properti-bantu-pulihkan-ekonomi-nasional.Diakses pada tanggal 27 Agustus 2021 pukul 20.46.

[4] Sulaksmono Haris.2019. Pemilihan Strategi Bisnis Properti di Kawasan Transit Oriented Development (Studi Kasus pada PT XYZ). Surabaya: Institut Teknologi Sepuluh November.

[5] Harjono K Dhaniswara. 2016. Hukum Properti. Jakarta: PPHBI (Pusat Pengembangan Hukum dan Bisnis Indonesia).

[6] Mukti Wedi Harini \& Solihin Mohamad. 2020. Kajian Investasi Pembangunan Perumahan (Studi Kasus : Perumahan Citra Dawuan Regency, Karawang). Jurnal Komposit. Civil Engineering and Environmental 2020. Vol 4 No.1 https://garuda.ristekbrin.go.id/documents/detail/1856461

[7] Rahayu Budi Tanama Putri. 2017. Manajemen Pemasaran. Denpasar : FP UNUD Denpasar.

[8] https://www.wartaekonomi.co.id/read301150/pandemi-covid-19-saatnya-berinvestasi- $\quad$ properti. Diakses 18 November 2020 pukul 19.45 .

[9] https://ekonomi.bisnis.com/read/20210617/47/1406912/saat-pandemi-covid-properti- masih-menjadi-primadonainvestasi . Diakses 20 Agustus 2021 pukul 10.19.

[10] Supiandi Gojali. 2020. Pengaruh Strategi Pemasaran dan Lokasi Terhadap Keputusan Pembelian pada PT. Tujuh Bintang Gemilang di Jakarta. Jurnal Ekonomi Efektif, Vol.2, No.3, April 2020. http://www.openjournal.unpam.ac.id/index.php/JEE/article/view/6801/6641

[11] Sugiyono.2016.Metode Penelitian Kuantitatif Kualitatif dan R\&D. Bandung : Alfabeta.

[12] Anggito, Albi \& Johan Setiawan. 2018. Metodologi Penelitian Kualitatif. Sukabumi: CV Jejak.

[13] Siyoto Sandu \& Ali Sodik. 2015.Dasar Metodologi Penelitian. Yogyakarta:Literasi Media Publishing.

[14] Barlian,Eri. 2016. Metodelogi Penelitian Kualitatif dan Kuantitatif. Padang; Sukabina Press. 
[15] Mamik. 2015. Metodologi Kualitatif. Sidoarja : Zifatama Publishing.

[16] Hardani,dkk.2020. Metode Penelitian Kualitatif \& Kuantitatif.Yogyakarta : CV.Pustaka Ilmu Group Yogyakarta.

[17] Mamik. 2015. Metodologi Kualitatif. Sidoarja : Zifatama Publishing

[18] Sanusi, Achmad. 2015. Manajemen Strategi. Pemasaran. Bandung : CV. Pustaka Setia

[19] Firli Tengku Musfar. 2020. Manajemen Pemasaran : Bauran Pemasaran sebagai Materi Pokok dalam Manajemen Pemasaran. Bandung : CV Media Sains Indonesia

[20] Firli Tengku Musfar. 2020. Manajemen Pemasaran :Bauran Pemasaran sebagai Materi Pokok dalam Manajemen Pemasaran. Bandung : CV Media Sains Indonesia.

[21] Ismail.2020. Manajemen Strategis Sektor Publik. Pasuruan : CV. Penerbit Qiara Media

[22] Wijayanti Titik. 2017. Marketing Plan! Dalam bisnis second edition. Jakarta : PT. Alex Media. 